\title{
Risk factors of Trichomonas vaginalis in women attending central Sexually Transmitted Diseases Clinic Sri Lanka
}

\author{
Sathyadevi Herath*, Deepika Fernando, Saman Jayasinge \\ From 17th International Symposium on HIV and Emerging Infectious Diseases (ISHEID) \\ Marseille, France. 23-25 May 2012
}

\section{Introduction}

Trichomonas vaginalis is one of the common infections among women attending Sexually Transmitted Disease Clinics (STD) of Sri Lanka. Yet majority with symptoms don't attend STD clinics and treated syndromically. In this scenario this study was carried out to identify risk factors of Trichomonas vaginalis in women inorder to review treatment by signs and symptoms.

\section{Methods}

Three hundred and fifty new female clinic attendees were recruited. Participants were interviewed on sociodemographic data, sexual history, symptoms, knowledge on STI/HIV, and condom use. Laboratory specimens were collected for theroutinescreening ofSTD diagnosis including Trichomoniasis.

\section{Results}

Mean age of the sample was 32.8 years (SD \pm 9.27 ). More than half $(223 ; 64 \%)$ were married. Approximately $53 \%$ had completed Grade 10 . Almost $76 \%$ tested positive being in $21-45$ years and $20 \%$ of positives were unmarried. Trichomoniasis prevalence was $7.2 \%$ (25 out of 346). Pruritus, vaginal discharge and vulvovaginal soreness, were significantly higher amongst positives $(\mathrm{P}<$ 0.05 for all). Educated women had higher risk $(\mathrm{OR}=3.0$; $\mathrm{CI}=1.28-7.26)$ of infection. Trichomoniasis was less common among women engaged in sex work $(\mathrm{OR}=0.3$; 95\% CI $=.0 .14-0.85)$, reported multiple sexual partners $(\mathrm{OR}=0.02 ; 95 \% \mathrm{CI}=0.073-0.408)$ and women reporting extra marital relationship $(\mathrm{OR}=0.3 \%, 95 \% \mathrm{CI}=0.123-0$. 733).

\footnotetext{
* Correspondence: sathya_herath@yahoo.com

Ministry of Health, Sri Lanka, Colombo, Sri Lanka
}

\section{Conclusions}

These findings are the reflection of female clinic attendees involving in commercial sex trade and high use of condoms amongst sex workers. It further emphasizes that the primary prevention activities are widespread especially among MARPs.

Findings also suggest that non use of condoms among women in monogamous relationship may contribute for Trichomoniasis thus HIV acquisition among housewives in Sri Lanka.

Published: 25 May 2012

doi:10.1186/1742-4690-9-S1-P42

Cite this article as: Herath et al:: Risk factors of Trichomonas vaginalis in women attending central Sexually Transmitted Diseases Clinic Sri Lanka. Retrovirology 2012 9(Suppl 1):P42.

Submit your next manuscript to BioMed Central and take full advantage of:

- Convenient online submission

- Thorough peer review

- No space constraints or color figure charges

- Immediate publication on acceptance

- Inclusion in PubMed, CAS, Scopus and Google Scholar

- Research which is freely available for redistribution

( 2012 Herath et al; licensee BioMed Central Ltd. This is an Open Access article distributed under the terms of the Creative Commons 